\title{
A new genus of the millipede tribe Brachyiulini (Diplopoda: Julida: Julidae) from the Aegean region
}

\author{
Eszter LAZÁNYI ${ }^{1,4} \&$ Boyan VAGALINSKI ${ }^{2,3,5}$ \\ ${ }^{1}$ Corresponding author: Department of Zoology, Hungarian Natural History Museum, Baross u. 13, \\ H-1088 Budapest, Hungary. E-mail: pesca12@gmail.com \\ ${ }^{2}$ Faculty of Biology, Sofia University, 8 Dragan Tsankov Blvd., 1164 Sofia, Bulgaria. \\ E-mail: boyan_vagalinski@excite.com \\ ${ }^{3}$ Institute of Biodiversity and Ecosystem Research, Bulgarian Academy of Sciences, 2 Yurii Gagarin \\ Street, 1113, Sofia, Bulgaria. \\ ${ }^{4}$ urn:1sid:zoobank.org:author:02DB48F1-624C-4435-AF85-FA87168CD85A \\ ${ }^{5}$ urn:1sid:zoobank.org:author:973B8725-039E-4F29-8D73-96A7F52CF934
}

\begin{abstract}
A new genus of the julid tribe Brachyiulini, Enghophyllum gen. nov., is described, comprising two species from Greece. The type-species, E. naxium (Verhoeff, 1901) comb. nov. (ex Megaphyllum Verhoeff, 1894), appears to be rather widespread in the Aegean: it is known from Antiparos Island and Naxos Island (the type locality), both in the Cyclades, as well as East Mavri Islet, Dodecanese Archipelago (new record). The vulva of E. naxium is described for the first time. In addition, E. sifnium gen. et sp. nov. is described based on a single adult male from Sifnos Island, Cyclades. The new genus is distinct from other genera of the Brachyiulini mainly by its peculiar gonopod structure, apparently disjunct and at least mostly apomorphous: (1) promeres broad, shield-like, in situ protruding mostly posteriad, completely covering the opisthomeres and gonopodal sinus; (2) transverse muscles and coxal apodemes of promere fully reduced; (3) opisthomere with three differentiated processes, i.e., lateral, basal posterior and apical posterior; (4) solenomere rather simple, tubular. The evolution and biogeography of the new genus are briefly discussed, both suggesting its profoundly long isolation in the Aegean region from the contribal genera in the adjacent Balkans and Anatolia.
\end{abstract}

Key words. Brachyiulus, Chromatoiulus, Megaphyllum, new taxa, new records.

Lazányi E \& Vagalinski B. 2013. A new genus of the millipede tribe Brachyiulini (Diplopoda: Julida: Julidae) from the Aegean region. European Journal of Taxonomy 70: 1-12. http://dx.doi.org/10.5852/ejt.2013.70

\section{Introduction}

The present paper continues our efforts in revising the large julid tribe Brachyiulini (Lazányi et al. 2012; Lazányi \& Vagalinski 2013; Vagalinski et al. 2013), this time being devoted to the description of a new oligotypic genus from several Aegean islands of Greece. Its type species, E. naxium (Verhoeff, 1901), previously referred to as Brachyiulus naxius, Chromatoiulus (Diaxylus) naxius or Megaphyllum naxium, has been found to occur both in the Cyclades and Dodecanese archipelagos, whereas the second congener, E. sifnium gen. et sp. nov., is a new species described below. The gonopod and, to some degree, the 
vulval structures of these two species appear to be of great interest by shedding additional light on the evolution and biogeography of the entire fauna of eastern Mediterranean Brachyiulini.

\section{Material and methods}

The present work is based on the examination of material from the Non-insect Invertebrate Collection, National Museum of Natural History (NMNHS), Sofia, and the Natural History Museum of Denmark, Zoological Museum, University of Copenhagen (ZMUC). Types of the new species are deposited in ZMUC. Specimens are stored in $70 \%$ ethanol and small dissected parts have been placed in genitalia vials which are kept together with the dissected individuals. Female vulvae were mounted on slides in Faure-Berlése medium and incubated at room temperature (around $25^{\circ} \mathrm{C}$ ) for several hours. After having been studied, the slides were put into distilled water, vulvae were removed from the Faure-Berlése medium and put into $70 \%$ ethanol.

Line drawings were made with a Leica M125 (HNHM) stereo microscope and an Olympus BX40 light microscope.

The apical end of the opisthomere is distinguished as the solenomere; all processes emerging from the opisthomere's main body are named simply according to their position as lateral, basal and apical posterior processes.

\section{Results}

Class Diplopoda Blainville-Gervais, 1844

Order Julida Leach, 1814

Family Julidae Leach, 1814

Tribe Brachyiulini Verhoeff, 1909

Genus Enghophyllum gen. nov.

urn:1sid:zoobank.org:act:15008961-CD77-4325-B694-13BA1F7E514E

\section{Type species}

Brachyiulus (Chromatoiulus) naxius Verhoeff, 1901

\section{Diagnosis}

A genus of Brachyiulini, differing from contribal genera by the following combination of characters: promere broad, shield-like, in situ protruding mostly posteriad, completely covering opisthomere and gonopodal sinus; transverse muscles and coxal apodemes of the promere fully reduced. Opisthomere with 3 well-differentiated processes: lateral $(l p)$, basal posterior (bpp) and apical posterior (app). Solenomere rather simple, tubular.

\section{Etymology}

This genus is named in honor of Prof. Henrik Enghoff from the ZMUC, not only for his vast contribution to our knowledge of diplopods, but also for his continuous encouragement and help during our work with Brachyiulini.

\section{Description}

Two frontal, four supralabral and 14-18 labral setae. Antennomeres 4 and 5 subequal in length (Fig. 1A). Gnathochilarium as on Fig. 1B. Metazona sparsely striated, as emphasised by Verhoeff (1901); ozopores right on the suture (Fig. 1C). Preanal process straight, anal valves sparsely pilose (Fig. 1D); subanal scale triangular, with protruding tip (Fig. 1E). 


\section{Males}

Mandibular stipes slightly protruding (Fig. 1F-G). First leg-pair like simple, rounded, somewhat converging hooks; the two hooks converging in an obtuse angle (Fig. 1H). Second leg-pair (Fig. 1I) with two ventral pads: on postfemur $(p f)$ and tibia $(t)$. Penis (Fig. 1J) significantly small, deeply hidden in penis sac, with two very short lobes and two rounded small lamellae running parallel, i.e., not diverging ( $r l$ and $l l$ for right and left lamella). Pleurotergum of the $7^{\text {th }}$ body ring protruding like a simple shovel (broken in the unique holotype of E. sifnium gen. et sp. nov., thus investigated only in E. naxium, see Fig.

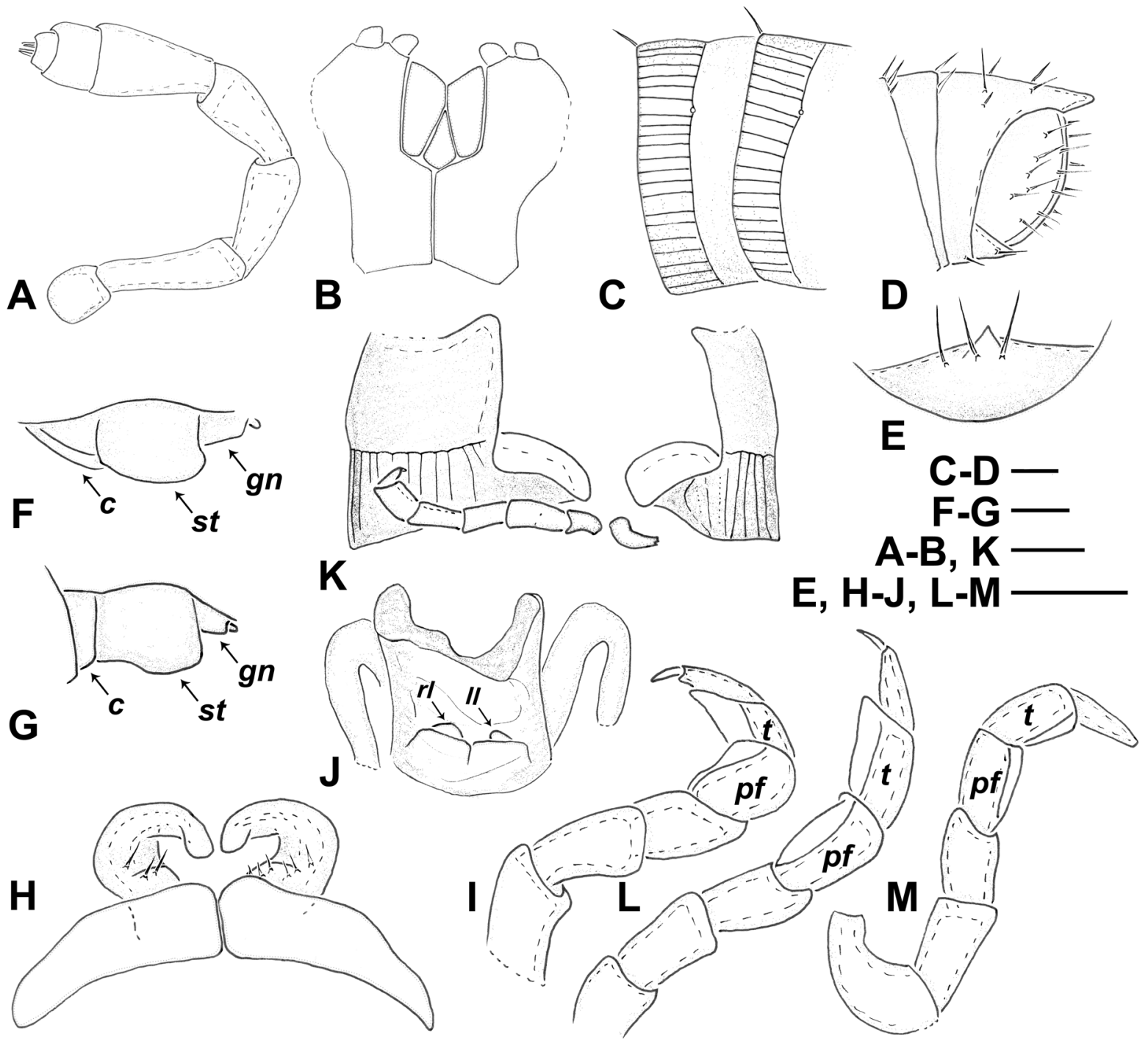

Fig. 1. Non-gonopod characters of Enghopyhllum gen. nov., males. A. Right antenna. B. Gnathochilarium. C. $8^{\text {th }}$ and $9^{\text {th }}$ body rings. D. Telson. E. Subanal scale. F. Mandibular stipital ("cheek") lobe, lateral view. G. Mandibular stipital ("cheek") lobe, ventro-lateral view. H. First leg-pair. I. Second leg-pair. J. Penis in the penis sac. K. Pleurotergum of the $7^{\text {th }}$ body ring, ventral view. L. Anterior left leg on the $6^{\text {th }}$ body ring. M. Anterior right leg on the $22^{\text {nd }}$ body ring. - A-D, F, H-I, L-M: E. sifnium gen. et sp. nov., holotype. E: E. naxium, from Antiparos. G, J-K: E. naxium, from Mavri Islet. 
$1 \mathrm{~K})$. Walking legs (Fig. 1L-M) with two ventral pads: on postfemur $(p f)$ and tibia $(t)$. Tarsus of midbody legs slightly longer than tibia: tarsus $/$ tibia $=(1.05-1.1) / 1$.

Gonopods noticeably big compared to body size, directed mostly posteriad. Promere bevelled in laterobasal corner to fit into the inner curve of the $7^{\text {th }}$ body ring; latero-basal corner of promere only with thin triangular lamella ( $t l$ ) (Fig. 2D-E). Promeres attached to each other in their meso-basal corner with a chitinous bridge. A short, oblique ridge $(r)$ on posterior surface of promere (Figs 2A, D-E, 4A, C). Flagellum emerging from a well-developed sinus $(f s i)$ (Fig. 2D-E). At the level of this sinus a deepening on anterior surface of the promere $(d)$ (Fig. 4B). Opisthomere entirely concealed under the promere, protruding postero-ventrad, the two promeres tightly closing the ventral opening on $7^{\text {th }}$ ring like a pair of shutters. Opisthomere not embedded in the groove formed by the oblique ridge on the promere's posterior surface (unlike in Megaphyllum), but "riding" on the ridge (Figs 2A, 4C): posterior basis of opisthomere with a characteristic riffle ( $r i$ ) formed by chitinous lamellae, where the ridge of the promere is positioned (Figs 2A, G, 4C-D). Opisthomere with a well-developed lateral process $(l p)$ and an apical and a basal posterior process ( $a p p$ and $b p p$ ). Solenomere $(s)$ simple, with no processes but basally with a micro-spinose pillow ( $m s p$ ) (Figs $2 \mathrm{~A}-\mathrm{C}, \mathrm{F}-\mathrm{G}, 4 \mathrm{~A}-\mathrm{D})$. Flagellum channel and sperm canal $(f c$ and $s c$ ) each with an apical opening (Fig. 4C).

\section{Females}

The only available female of E. sifnium gen. et sp. nov. is in stadium IX (with 8 rows of ocelli) and proved to be subadult, but females of E. naxium in stadia VIII-IX (with 7-8 rows of ocelli) had fully developed vulvae, which we used here for the description of female sexual characters. First two legpairs slightly swollen.

Vulva (Fig. 3): Subcylindric in shape, the mesal half shorter, the opening large, oval, apical. Operculum shorter than bursa, with around 20-25 setae. Mesal and lateral sclerites with 2-3 setae each. Apodematic tube not opening apically into a longitudinal median cleft as in, e.g., Megaphyllum species, but into a wide sinus ( $\mathrm{si}$ ). Around this sinus a thin wall, formed by the apical part of the bursa. These walls with small dot-like pores; most setae (around 20/side) emerging from this apical region. Apodematic tube (at) ending in two receptaculi seminis or ampullae. Central ampulla $(c a)$ drop-like. Distal, globular ampulla $(d a)$ joining the apodematic tube through a twisted connecting tube $(c t)$. Connecting tube very long, thus the distal ampulla hanging out of the bursa; easily broken off during preparation.

\section{Remarks}

The everted penes of the adult E. naxium male from Antiparos was quite soft, amorphous and huge, contrary to the stout, minute penes, deeply hidden under the $2^{\text {nd }}$ leg-pair coxae, observed in the $E$. naxium male from Mavri Islet and the E. sifnium gen. et sp. nov. male from Sifnos. It is possible that penes vary in size between copulating and non-copulating periods.

Enghophyllum sifnium gen. et sp. nov. urn:1sid:zoobank.org:act:5327BB09-7438-47BD-9D91-BBC6FE7F1CC5

Figs 1A-D, F, H-I, L-M, 2A-G, 5

\section{Diagnosis}

Differs from the only congener, E. naxium (Verhoeff, 1903), by the apical margin of the promere being slightly convex and the opishtomere being significantly compressed meso-laterad.

\section{Etymology}

Named after the type locality, the island of Sifnos, Cyclades. 


\section{Material examined}

\section{Holotype}

GREECE: đ̂̃, Hellas [Greece], Kikladhes [Cyclades], Sifnos Island, Pharos [Faros], 11.ii.1990 [11 Feb. 1990], S. Sfendourakis leg., ex coll. Karamaouna, "Megaphyllum aff. naxium (Verhoeff, 1901)" M. Karamouna det. (ZMUC).
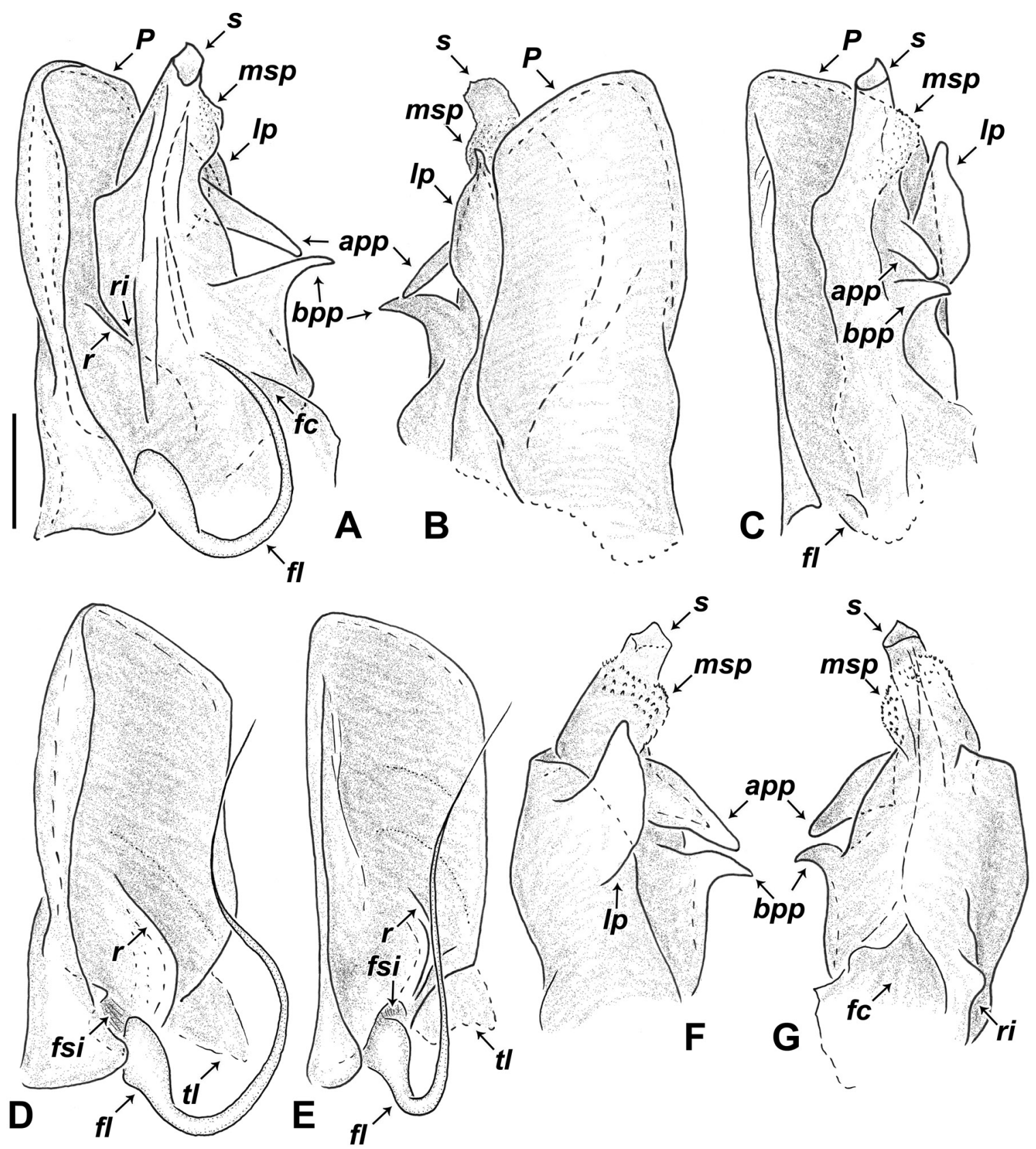

Fig. 2. Gonopods of Enghophyllum sifnium gen. et sp. nov., holotype $\widehat{~}$. A. Left gonopods, mesal view. B. Leftgonopods, antero-lateralview.C.Leftgonopods, meso-posterior view. D. Left promere, meso-posterior view. E. Left promere, postero-mesal view. F. Right opisthomere, lateral view. G. Right opisthomere, mesal view. $-a p p=$ apical posterior process; $b p p=$ basal posterior process; $f c=$ flagellum channel; $f=$ flagellum; $f s i=$ flagellum sinus; $l p=$ lateral process; $m s p=$ micro-spinose pillow; $P=$ promere; $r=$ ridge; $r i=$ riffle; $s=$ solenomere; $t l=$ triangular lamella. Scale bar: $0.2 \mathrm{~mm}$. 
Paratypes

GREECE: 1 juv. $\widehat{\jmath}, 1$ juv. . . Same collection data as holotype (ZMUC).

\section{Description}

Holotype male in stadium $X$ (with 9 rows of ocelli); body ring number: 41 podous +2 apodous + telson; length $18.8 \mathrm{~mm}$; height $1.1 \mathrm{~mm}$; ocelli: right side: 35 , left side: 33 . Additional measurements of the adult male: promentum around twice as long as wide (Fig. 1B), tibia of midbody legs slightly longer than tarsus, $4^{\text {th }}$ antennal article as long as $5^{\text {th }}$ (Fig. 1A). Subadult paratype male in stadium IX (with 8 rows of ocelli); body ring number: 38 podous +3 apodous + telson; length $13.1 \mathrm{~mm}$; height $1.1 \mathrm{~mm}$; ocelli: right side: 34 , left side: 35 . Subadult female in stadium IX (with 8 rows of ocelli); body ring number: 39 podous +3 apodous + telson; length $14.1 \mathrm{~mm}$; height $1 \mathrm{~mm}$; ocelli: right side: 30 , left side: $30.17-18$ labral bristles.

Colour. Basic colour yellowish-beige (obviously faded) with a narrow brownish middorsal band, divided by a white median line. Two wider, diffused brownish bands at ozopore level, more intensely coloured around the ozopores.

SCULPTURE. Collum smooth, with only several short striae visible; metazona sparsely striated (Fig. 1C), somewhat denser on dorsal side, posterior margin with long, erect setae. Scarce, short striae also on prozona.

Telson (Fig. 1D). Anal valves covered with scarce, long setae and a row of much shorter setae along each valve's caudal margin. Preanal process without any setae in the adult male, but with a few setae in the two subadults; straight, stout, protruding near to the level of the longest anal setae (for the adult male). Subanal scale triangular, with a rounded tip, slightly protruding behind rear contour of anal valves; with two pairs of long setae laterally.

Gonopods (Fig. 2A-G). Promere (Fig. 2D-E and $P$ on Fig. 2A-C) wide, slightly narrowing apically towards mesal margin. Apical margin convex, mesal and lateral margins almost parallel, the lateral one slightly sinuous. Opisthomere with three processes: a flat lateral process ( $l p$ on Fig. 2A-C, F), a slightly curved, rod-like basal posterior process (bpp on Fig. 2A-C, F-G) and an elongate, massive, rod-like apical posterior process ( $a p p$ on Fig. 2A-C, F-G); all processes well-developed, tapering and not furcated. A micro-spinose pillow ( $m s p$ ) around the base of solenomere ( $s$ ) (Fig. 2A-C, F-G). Entire opisthomere strongly compressed meso-laterad (compare Fig. 2C with Fig. 4A).

Female adults unknown.

Enghophyllum naxium (Verhoeff, 1901) comb. nov.

Figs 1E, G, J-K, 3, 4A-D, 5

Brachyiulus (Chromatoiulus) naxius Verhoeff, 1901: 98-99, fig. 21.

Chromatoiulus naxius - Attems 1927: 222 (in key). - Strasser 1974: 290, 295. — Ceuca 1992: 425.

Chromatoiulus (Diaxylus) naxius - Attems 1940: 307, 311-312.

Megaphyllum naxium - Mauriès \& Karamaouna 1984: 55-56, figs 7-9. — Enghoff \& Kime 2009. Lazányi et al. 2012: 21, 41.

\section{Diagnosis}

Differs from the only congener E. sifnium gen. et sp. nov. by the apical margin of the promere being concave, the opisthomere not compressed meso-laterad, e.g., the lateral process ( $l p$ on Fig. 4A-D) parallel to the promere, the lateral process $(l p)$ much broader and the apical posterior process (app) broader and blunter. 


\section{Material examined}

GREECE: 1 đ , 2 qo , Antiparos Island, litière [litter], 22 Dec. 1982, leg. P. Beron \& St. Andreev, det. Mauriès 1983 (NMNHS); 1 đ̂, Sporadhes, Anatoliko Mauri [east Mavri Islet] (Levitha Islands), 18.i.1990 [18 Jan. 1990], S. Sfendourakis leg., ex coll. M. Karamaouna (ZMUC).

\section{Remarks}

Male body length 16.9-17.9 mm; height 1-1.2 mm; body ring number: 39-41 podous rings + 2-3 apodous rings + telson; number of ocelli: right side: 30-38, left side: 32-38; developmental stadium IX-X with

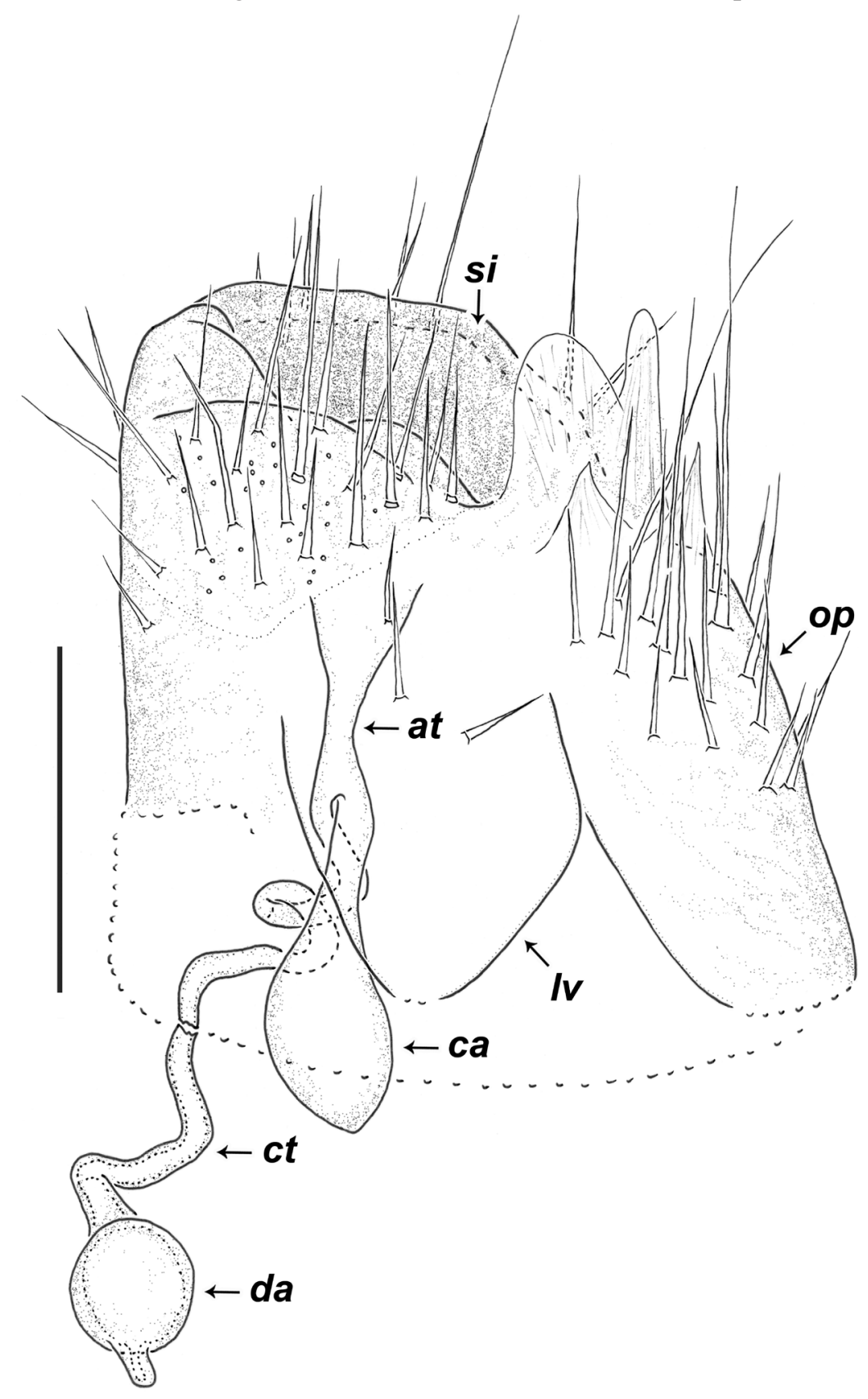

Fig. 3. Right vulva of Enghophyllum naxium, female from Antiparos Island, anterior view. $a t=$ apodematic tube; $c a=$ central ampulla; $c t=$ connecting tube; $d a=$ distal ampulla; $l v=$ lateral valve; $o p=$ operculum; $s i=$ sinus. Scale bar: $0.2 \mathrm{~mm}$. 
8-9 rows of ocelli. Female body length 13.4-18.3 mm; height 1-1.3 mm; body ring number: 37-41 podous rings $+3-5$ apodous rings + telson; developmental stadium VIII-IX with 7-8 rows of ocelli.

This species was described on the basis of two males and four females and has only been found once since its description, viz., by Mauriès \& Karamaouna (1984) from Antiparos. The new specimens from east Mavri belong to the collection of Karamaouna, but they are slightly different: the apical posterior process (app) of the solenomere is not bifurcated, but undivided and slightly serrated (serration visible in posterior view) (Fig. 4A, C-D).
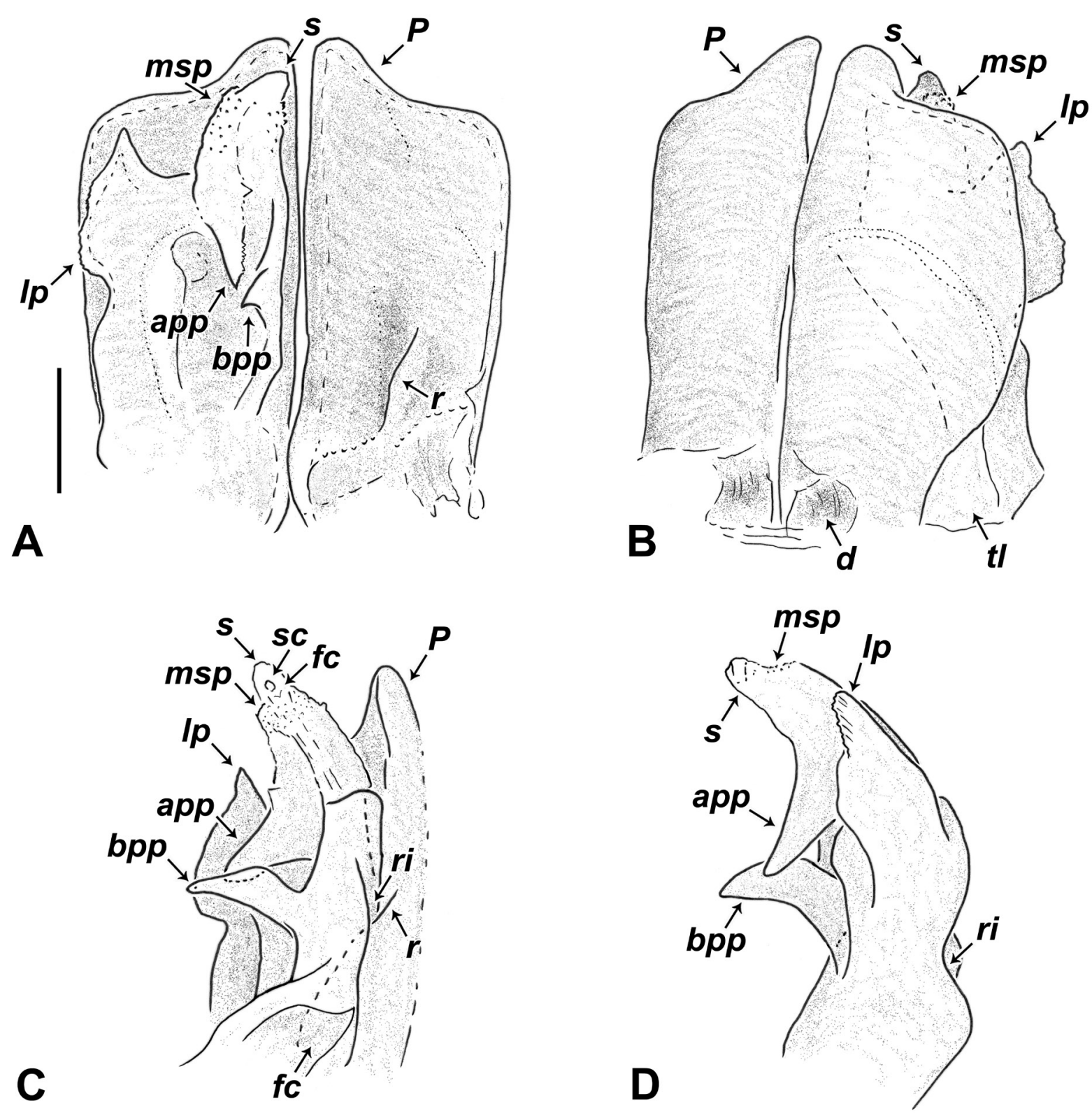

Fig. 4. Gonopods of Enghophyllum naxium, male from Mavri Islet. A. Gonopods, posterior view. B. Gonopods, antero-lateral view. C. Right gonopods, mesal view. D. Left opisthomere, lateral view. $-a p p=$ apical posterior process; $b p p=$ basal posterior process; $d=$ deepening; $f c=$ flagellum channel; $l p=$ lateral process; $m s p=$ micro-spinose pillow; $P=$ promere; $r=$ ridge; $r i=$ riffle; $s=$ solenomere; $s c=$ sperm canal; $t l=$ triangular lamella. Scale bar: $0.2 \mathrm{~mm}$. 


\section{Distribution}

Greece: Cyclades: Naxos Island (type locality), Antiparos Island (Mauriès \& Karamaouna 1984); Dodecanese Islands: east Mavri Islet.

\section{Discussion}

Enghophyllum naxium was hitherto treated as a Megaphyllum species (or under its former synonyms Chromatoiulus and Brachyiulus s. auct.) (Lazányi et al. 2012). It was placed in the subgenus Diaxylus Attems, 1940 (type species: Chromatoiulus anatolicus Attems, 1927) on the basis of having a simple promere, a simple solenomere, a posterior process at right angles to the opisthomere and lacking a bristle-row along the flagellum channel (Attems 1940). After thorough investigations of this species and of E. sifnium gen. et sp. nov., supplemented with the examination of Megaphyllum argolicum (Verhoeff, 1900), M. asiaeminoris (Verhoeff, 1898), M. euphorbiarum (Verhoeff, 1900) and M. anatolicum (Attems, 1927), all referred to Diaxylus, it became apparent that E. naxium and E. sifnium gen. et sp. nov. form a group neither with the aforementioned species, nor with any other Megaphyllum subgenus or Brachyiulini genus. The combination of external morphological characters together with male and female genitalia characters supports the establishment of a new brachyiuline genus: Enghophyllum gen. nov. Considering gonopodal structure, some similarities with Megaphyllum byzantinum (placed in the monotypic subgenus Byzantorhopalum Verhoeff, 1930) can be discerned, namely the well-developed lateral process of the opisthomere and the cylindrical vulvae with a mostly apically positioned opening. However, some external and internal features of the vulvae, the shape of the penes, and notably the unique arrangement of the promeres leave no doubt that these species belong to a different genus.

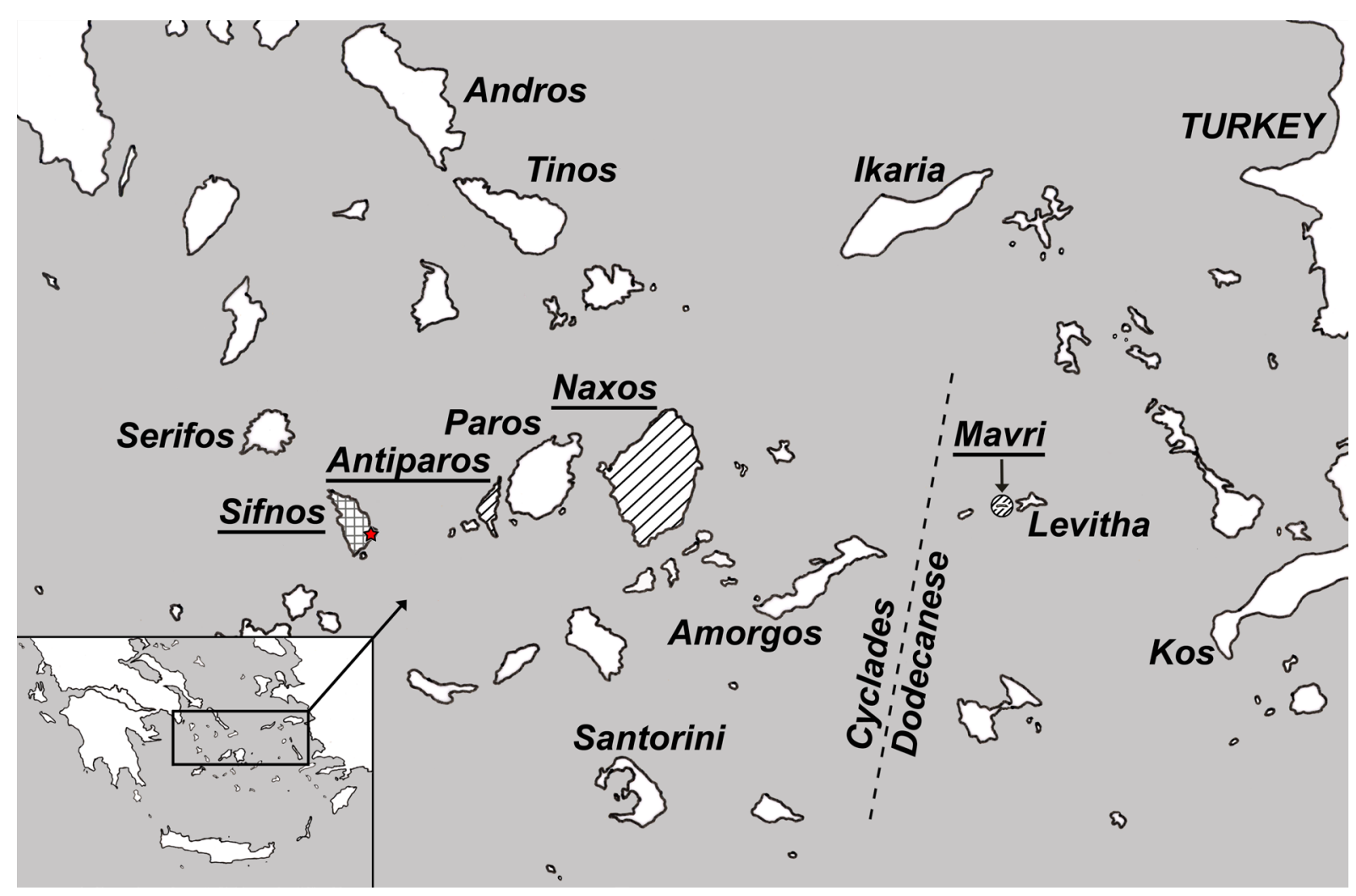

Fig. 5. Distribution map of Enghophyllum gen. nov. The checked area (Sifnos Island) represents the possible distribution of E. sifnium gen. et sp. nov.; the red star shows Faros, its type locality. The obliquely lined areas (Antiparos and Naxos Islands, Mavri Islet) show the distribution of E. naxium. 
The known distribution of Enghophyllum gen. nov. is so far restricted to three islands in the Cyclades (Naxos, Antiparos and Sifnos) and one small islet in the westernmost part of the Dodecanese Islands, Greece (east Mavri Islet, Fig. 5). There are currently 10 other species of Brachyiulini reported from the Aegean Islands: Brachyiulus stuxbergi (Fanzago, 1875) (Crete), Megaphyllum bicolor (Loksa, 1970) (Rhodos, Naxos), M. brachyurum (Attems, 1899) (Thasos), M. chiosense Lazányi \& Korsós, 2012 (Chios), M. creticum (Strasser, 1976) (Crete), M. mueggenburgi (Verhoeff, 1901) (Karpathos, Kasos), M. rossicum (Timotheew, 1897) (Samothraki), M. sapphicum (Strasser, 1976) (Lesvos), M. syrense (Verhoeff, 1903) (Syros) and M. taygeti (Strasser, 1976) (Crete) (Felesaki et al. 2010; Lazányi et al. 2012). Most of them are known only from a single island, except for M. mueggenburgi, which inhabits the adjacent Karpathos and Kasos, and M. bicolor with its nominotypical subspecies described from Rhodos and the subspecies $M$. b. crassiflagellum described from Naxos. It is also notable that only 4 species, namely $B$. stuxbergi, $M$. brachyurum, $M$. taygeti and $M$. rossicum, occur both on islands and on either European or Asian mainlands. B. stuxbergi is widely distributed in Greece and Italy; $M$. brachyurum is represented on Thasos with its subspecies $M$. $b$. thassensis, while the nominotypical subspecies inhabits the Caucasian region; M. taygeti occurs on the Peloponnese; M. rossicum rossicum is widely distributed in South Russia and the Ukraine, while M. r. strandschanum has been reported from south Bulgaria and northeast continental Greece, apart from the single record from Samothraki.

The Aegean Islands seem to support a high number of endemics of the Brachyiulini tribe, the most outstanding of which are the two species of Enghophyllum gen. nov. Compared to a number of biogeographic and phylogeographic papers dealing with different invertebrate groups from the Aegean region (e.g., Douris et al. 2007; Fattorini \& Fawles 2005; Sfenthourakis 1996; Welter-Schultes \& Williams 1999) the above described distribution pattern of the Aegean Brachyiulini is especially similar to that observed by Heller (1976). He found most Aegean species of the terrestrial gastropod family Enidae to occur only on one or several adjacent islands, which is considered to reflect the lack of active immigration in recent geological times. These biogeographic similarities could be explained with the very limited dispersal abilities characteristic of millipedes and land snails in general. Another reason may be the rather weak ecological specialization common to both groups. Thus, their current distribution would be less affected by the presence/absence of particular plant communities or habitat degradation, unlike the case with, e.g., the central Aegean Oniscidea (Sfenthourakis 1996), and would more clearly reflect the geological events that took place in the Aegean region. In this respect the record for E. naxium from east Mavri may present interesting information in terms of further revealing the biogeographic affiliations of this group of several small islands (Kinaros, west and east Mavri and Levitha), positioned between the Cyclades and the Dodecanese although officially ascribed to the latter. Sfenthourakis (1996) suggested that Mavri is biogeographically related to several scattered islands in the south Cyclades, while Levitha has more in common with the other Dodecanese islands. However, the overal scarce faunistic data hamper any firm conclusions being reached about the islets' paleogeographic history.

In spite of the rather few distribution records for the new genus, as well as the insufficiently investigated millipede fauna of the Greek islands in general, we may suppose that the genus described here represents a distinct lineage of Brachyiulini that has developed in relatively long-lasting isolation, as there are currently no apparent closely related forms in the Balkans or in Anatolia. The relict character of the Aegean fauna has already been demonstrated for other invertebrate groups like tenebrionid beetles (Fattorini \& Fawles 2005) and land snails (Heller 1976; Welter-Schultes \& Williams 1999).

In conclusion, it can be assumed that Enghophyllum gen. nov. confirms the importance of the Aegean Islands together with south Greece and west Turkey for the evolution of the millipede tribe Brachyiulini, being inhabited by both highly distinct local forms, as well as by members of (sub)genera and species groups found in other regions - evidence of successive processes of migration and vicariance resulting 
in intense speciation. On the other hand, the dominant position of the tribe in terms of species richness among Diplopoda from the region, combined with a high rate of endemism, provide good reasons for using the group as a model for further elucidation of the complicated paleogeographic history of the Aegean Archipelago.

\section{Acknowledgements}

We would like to thank Prof. Henrik Enghoff at the Natural History Museum of Denmark and Prof. Pavel Stoev at the National Museum of Natural History, Bulgaria for their help and the arrangement of loans of type and non-type specimens.

\section{References}

Akkari N., Stoev P. \& Enghoff H. 2011. Two new cavernicolous genera of Julidae (Diplopoda, Julida), with notes on the tribe Brachyiulini and on julid subanal hooks and anchors. Zookeys 114: 1-14. http:// dx.doi.org/10.3897/zookeys. 114.1490

Attems C. 1927. Über palaearktische Diplopoden. Archiv für Naturgeschichte 92 (1-2): 1-256.

Attems C. 1940. Beiträge zur Kenntnis der Iuliden. Annalen des Naturhistorischen Museums in Wien 50: 294-327.

Ceuca T. 1992. Quelques aspects sur la faunistique, l'écologie et la zoogeographie des diplopodes de la Région Balkanique. In: Meyer E., Thaler K. \& Schedl W. (eds) Advances in Myriapodology, Berichte des naturwissenschaftlich-medizinischen Vereins in Innsbruck, Supplement 10: 411-429.

Douris G., Giokas S., Thomaz D., Lecanidou R. \& Rodakis G.C. 2007. Inference of evolutionary patterns of the land snail Albinaria in the Aegean archipelago: Is vicariance enough? Molecular Phylogenetics and Evolution 44 (3): 1224-1236. http://dx.doi.org/10.1016/j.ympev.2007.01.004

Enghoff H. \& Kime D. 2009. Fauna Europaea: Diplopoda. Fauna Europaea version 2.0 [online]. Available from http://www.faunaeur.org (accessed 17 Aug. 2011)

Felesaki I., Stoev P., Simaiakis S.M. \& Mylonas M. 2010. A catalogue of the millipedes of Crete (Myriapoda: Diplopoda). Natura Montenegrina 9 (3): 357-368.

Fattorini S. \& Fowles A.P. 2005. A biogeographical analysis of the tenebrionid beetles (Coleoptera, Tenebrionidae) of the island of Thasos in the context of the Aegean Islands (Greece). Journal of Natural History 39 (46): 3919-3949. http://dx.doi.org/10.1080/00222930500533443

Heller J. 1976. The biogeography of Enid snails of the Aegean Islands. Journal of Biogeography 3: 281-392.

Lazányi E. \& Korsós Z. 2011. Revision of the Megaphyllum projectum Verhoeff species complex (Myriapoda: Diplopoda: Julida: Julidae). Zootaxa 2864: 43-56.

Lazányi E. \& Vagalinski B. 2013. Redefinition of the millipede subgenus Megaphyllum sensu stricto Verhoeff, 1894 and neotype designation for Megaphyllum austriacum (Latzel, 1884) (Myriapoda: Diplopoda: Julida: Julidae). Zootaxa 3741: 55-100. http://dx.doi.org/10.11646/zootaxa.3741.1.2

Lazányi E., Vagalinski B. \& Korsós Z. 2012. The millipede genus Megaphyllum Verhoeff, 1894 in the Balkan Peninsula, with description of new species (Myriapoda: Diplopoda: Julida: Julidae). Zootaxa 3228: 1-47.

Mauriès J-P. \& Karamaouna M. 1984. Myriapodes-Diplopodes nouveaux et peu connus des îles Naxos, Paros et Antiparos (Cyclades, Grèce). Biologia Gallo-hellenica 11: 51-59. 
Sfenthourakis S. 1996. A biogeographical analysis of terrestrial isopods (Isopoda, Oniscidea) from the central Aegean islands (Greece). Journal of Biogeography 23: 687-698. http://dx.doi. org/10.1111/j.1365-2699.1996.tb00029.x

Strasser K. 1974. Über Diplopoda-Chilognatha Griechenlands. Revue Suisse de Zoologie 81 (1): 219300 .

Vagalinski B., Lazányi E. \& Golovatch S. 2013. Redescription of the subgenus Parancistrum Verhoeff, 1943, an eastern Mediterranean lineage of the millipede genus Megaphyllum Verhoeff, 1894 (Diplopoda: Julida: Julidae: Brachyiulini). Zootaxa 3734: 501-520. http://dx.doi.org/10.11646/zootaxa.3734.5.1

Verhoeff C. 1901. Beiträge zur Kenntniss paläarktischer Myriopoden. XVII. Aufsatz: Diplopoden aus dem Mittelmeergebiet. Archiv für Naturgeschichte 67 (1): 79-102.

Welter-Schultes F.W. \& Williams M.R. 1999. History, island area and habitat availability determine land snail species richness of Aegean Islands. Journal of Biogeography 26: 239-249. http://dx.doi. org/10.1046/j.1365-2699.1999.00276.x

Manuscript received: 1 July 2013

Manuscript accepted: 8 November 2013

Published on: 17 December 2013

Topic editor: Rudy Jocqué

Desk editor: Danny Eibye-Jacobsen

Printed versions of all papers are also deposited in the libraries of the institutes that are members of the EJT consortium: Muséum National d'Histoire Naturelle, Paris, France; National Botanic Garden of Belgium, Meise, Belgium; Royal Museum for Central Africa, Tervuren, Belgium; National History Museum, London, United Kingdom; Royal Belgian Institute of Natural Sciences, Brussels, Belgium; Natural History Museum of Denmark, Copenhagen, Denmark. 